\title{
Strategies and Challenges in Conventional and Digital Film Distribution and Exhibition in Indonesia
}

\section{Strategi Dan Tantangan Dalam Distribusi Dan Eksibisi Film Secara Konvensional Maupun Digital Di Indonesia}

\author{
Cici Eka Iswahyuningtyas ${ }^{1}$, dan Mochammad Fadjar $\mathrm{H}^{2}$ \\ ${ }^{1}$ Fakultas Ilmu Komunikasi, Universitas Pancasila, Jl. Srengseng Sawah, Jagakarsa, Jakarta \\ Selatan 12640* \\ Email: ciciekaiswahyuningtyas@univpancasila.ac.id \\ ${ }^{2}$ Fakultas Ilmu Komunikasi, Universitas Pancasila \\ Email:fadjar.24.h@gmail.com
}

\begin{abstract}
Today, media distribution and consumption can occur anytime, anywhere, anything, both conventional and digital. The change in media consumption behavior has brought many challenges for the Indonesian film industry, particularly distribution and exhibition. Film distribution should not just rely on the domestic market and film exhibitions through cinemas. The number of Indonesian cinemas and screens is not ideal, still concentrated in big cities, has low moviegoers, is dominated by foreign films, and lacks support from the government. This study intended to identify challenges and strategies for conventional and digital distribution and exhibition. Answer to that question, this study was carried qualitatively by conducting a literature review through meta-analysis related to history, experiences, and situations in some countries. Research findings indicate film distribution and exhibition need to run simultaneously conventional and digital. Digital distribution is urgent for expanding market size and cinemas revenue. The conventional distribution needs to be maintained because the highest film revenue still comes from cinemas exhibitions. Therefore, filmmakers should begin to organize their distribution strategy and expand cooperation with digital film providers. The government needs to build distribution infrastructures such as global film festivals and distribution agencies, also create policies related to exhibition incentives and tax rebates, especially for films with small audiences.
\end{abstract}

Keywords: challenges and strategies, conventional and digital media, film distribution and exhibition, government policy, Indonesia film industry

\begin{abstract}
Abstrak
Distribusi dan konsumsi media dewasa ini dapat dilakukan kapanpun, dimanapun, apapun, baik secara konvensional maupun digital. Perubahan perilaku konsumsi media membawa banyak tantangan bagi industri film di Indonesia, khususnya terkait aspek distribusi dan eksibisi. Distribusi film tidak boleh hanya bergantung pada pasar domestik dan mengandalkan eksibisi film melalui bioskop. Hal ini karena jumlah bioskop dan layar yang tersedia di Indonesia belum ideal, masih terpusat di kota besar, memiliki sedikit penonton, berada dalam dominasi film asing dan kurang mendapatkan dukungan dari pemerintah. Kajian ini dimaksudkan untuk mengetahui tantangan dan strategi dalam distribusi dan
\end{abstract}


eksibisi film secara konvensional dan digital. Untuk menjawab pertanyaan tersebut kajian ini dilakukan secara kualitatif dengan melakukan kajian pustaka melalui analisis meta terkait sejarah, pengalaman, situasi yang terjadi di beberapa negara. Temuan penelitian menunjukkan bahwa distribusi dan eksibisi film perlu dilakukan secara simultan. Distribusi digital penting untuk memperluas pasar dan meningkatkan pendapatan. Distribusi konvensional perlu dipertahankan karena pendapatan film terbesar masih berasal dari distribusi melalui jalur bioskop. Oleh karena itu, pembuat film harus mulai mengatur sendiri strategi distribusinya dan meningkatkan kerjasama dengan provider film digital. Pemerintah perlu membangun infrastruktur distribusi seperti festival film dan agensi distribusi di tingkat global, dan membuat kebijakan terkait pemberian insentif eksibisi dan potongan pajak, khususnya bagi film dengan sedikit penonton.

Kata Kunci: distribusi dan eksibisi, industri film Indonesia, kebijakan pemerintah, media konvensional dan digital, strategi dan tantangan

\section{Pendahuluan}

Perubahan gaya hidup dan pola konsumsi media dari konvensional ke digital membawa banyak perubahan bagi industri film tanah air, khususnya terkait distribusi dan eksibisi. Film yang sebelumnya mengandalkan eksibisi melalui jalur bioskop saat ini bergeser ke platform digital berbasis Subscription Video on Demand (SVoD) seperti Viu, Netflix, iFlik, GoPlay, Genflix, Disney+Hotstar, dll. Bahkan meskipun belum sepopuler $S V o D$, bioskop kontemporer atau digital saat ini juga sudah mulai berkembang dan diminati. Hal ini karena hanya dengan membayar sepuluh ribu rupiah penonton dapat menonton film secara legal, tanpa perlu pergi ke bioskop, dan tentunya aman dari resiko terpapar virus Covid-19. Meskipun Industri film masih mengandalkan pendapatan dari bioskop tetapi melihat trend pergeseran ruang eksibisi film global ke platform digital dan pertumbuhan bisnis SVoD nasional yang terus menunjukkan peningkatan khususnya sejak terjadinya pandemi Covid-19 menunjukkan tingginya peluang pasar film digital untuk dikembangkan. Peluang tersebut tentunya perlu direspon secara strategis dan simultan untuk memaksimalkan perolehan penonton di tingkat nasional dan global. Perlu diketahui bahwa market share film nasional saat ini hanya sebesar $35 \%$ dan jumlah tersebut menjadi jauh lebih kecil di tingkat global (Mardianto et al., 2019).

Apalagi sektor ekonomi kreatif beberapa tahun ini juga terus menunjukkan trend peningkatan, bahkan sukses menggeser posisi sektor ekonomi Migas yang telah berpuluh-puluh tahun mendominasi ekonomi dunia. Dibandingkan sektor ekonomi kreatif lainnya, film menempati posisi lebih strategis untuk dikembangkan karena film dipercaya mampu menggerakkan sektor ekonomi lainnya. Sebagai contoh Korea Selatan, kemajuan ekonomi di negara tersebut terjadi karena keberhasilannya dalam mensinergikan industri budaya dengan industri otomotif dan elektronik. Melalui film dan drama, Korea Selatan tidak saja sukses memajukan industri pariwisata, kuliner, fashion, kosmetik, dll tetapi juga menjadikan industri otomotif dan elektroniknya diakui dunia. Ini artinya, kemajuan industri film tidak hanya penting untuk meningkatkan pendapatan bagi pelaku usaha film tetapi juga meningkatkan pendapatan ekonomi secara keseluruhan. 
Cici Eka Iswahyuningtyas ${ }^{1}$, dan Mochammad Fadjar H:

Strategies and Challenges in Conventional and Digital Film Distribution and Exhibition in Indonesia Strategi Dan Tantangan Dalam Distribusi Dan Eksibisi Film Secara Konvensional Maupun Digital Di Indonesia

Berbeda dengan era sebelumnya yang lebih mengedepankan tahap produksi, saat ini tahap paska produksi, yaitu distribusi dan eksibisi menjadi faktor penentu keberhasilan suatu film. Distribusi diperlukan untuk memperluas pasar dan menghubungkan tahap produksi dengan konsumsi atau menghubungkan pembuat film dengan penontonnya (Smits et al., 2018). Ini artinya pelaku usaha film dan pemerintah perlu segera mengambil langkah strategis dan menempatkan tahap paska produksi sebagai bagian penting dalam upaya pengembangan industri film nasional.

Potensi industri media, khususnya film dapat dilihat dari data statistik media di Indonesia yang tubuh 11\% dengan nilai \$ 8.9 milyar pada tahun 2016 atau rerata dari tahun 2012-2015 tumbuh sebesar 12.5\%. Broadcasting dan TV kabel memperoleh pendapatan terbesar yaitu $67.1 \%$, disusul sektor Percetakan $15.3 \%$, Periklanan 12.7\%. Di tingkat Asia Pasifik, persentase pendapatan industri media menunjukkan situasi yang tidak jauh berbeda. Nilai industri media di Indonesia sebesar 3.3\%, nilai tertinggi dipegang oleh Cina dengan nilai sebesar 40.2\%, kemudian Jepang 28.4\%, India 7\% dan Korea Selatan 4.9\% (Asia-Pacific-Media MarketLine Industry Profile Media in Asia-Pacific, 2017).

Di tingkat global industri media tumbuh sebesar 0.9\% pada tahun 2016 dengan nilai ekonomi sebesar \$ 876.1 Milyar. Rerata pertumbuhan industri media global tahun 2012-2016 sebesar 1.6\%. Pendapatan terbesar diperoleh TV kabel dan broadcasting sebesar $50 \%$, penerbitan $29.6 \%$, periklanan $11.2 \%$ kemudian film dan hiburan 9.2\% (MarketLine Industry Profile Global Media, 2014). Khusus industri film, tahun 2019 untuk pertama kalinya pasar film global mendapatkan $\$ 100$ Milyar atau naik 8\% dibandingkan tahun 2018. Sedangkan pendapatan untuk semua film box office di tingkat global pada tahun yang sama mencapai $\$ 42.2$ Milyar atau naik 1\% dibandingkan tahun sebelumnya (Motion Picture Association, 2019). Meskipun pendapatan sektor industri film lebih rendah dibandingkan sektor industri media lainnya tetapi industri film menunjukkan trend pertumbuhan yang lebih tinggi. Bahkan pada tahun 2019 industri film global tumbuh 10\% dan diperkirakan akan terus menunjukkan pertumbuhan positif pada tahun-tahun berikutnya.

Selanjutnya, dilihat dari aspek konsumsi media di tingkat global. Konsumsi media digital juga menunjukkan trend peningkatan, sebaliknya konsumsi media konvensional justru cenderung menurun. Rerata konsumsi media digital meningkat dari 5 jam 37 menit di tahun 2012 menjadi 6 jam 45 menit di tahun 2018. Sedangkan media tradisional mengalami penurunan, dari 4 jam 36 menit menjadi 4 jam 33 menit. Di Indonesia sendiri rerata konsumsi media digital harian adalah 8 jam 25 menit, sedangkan media tradisional 4 jam 47 menit (Gobalwebindex, 2019).

Data penonton film global tahun 2019 menunjukkan 42\% menonton film di bioskop, $48 \%$ menonton secara digital dan sisanya $10 \%$ menonton melalui pembelian rilisan fisik (DVD). Di Amerika sendiri jumlah penonton film digital jauh lebih tinggi dibandingkan data di tingkat global, yaitu sebesar 56\% sedangkan penonton film bioskop sebesar 31\%, dan rilisan fisik 13\% (Motion Picture Association, 2019). Kondisi tersebut menunjukkan bahwa telah terjadi perubahan signifikan terkait pilihan ruang eksibisi film, jika sebelumnya terkonsentrasi di bioskop sekarang ini mulai bergeser ke ruang digital. Sayangnya, saat ini perhatian 
dan dukungan pemerintah pada industri film masih terpusat pada tahap produksi misalnya, dengan pemberian subsidi produksi film. Padahal temuan penelitian menunjukkan bahwa subsidi film secara langsung dalam jumlah besar sekalipun tidak menjamin keberhasilan film seperti yang terjadi di Eropa (Messerlin, 2019).

Berbeda dengan sektor industri kreatif lainnya, bisnis film memiliki resiko lebih tinggi. Kondisi ini tercipta karena bisnis film membutuhkan investasi besar dan umumnya tidak memiliki asuransi. Pembuat film juga tidak dapat memastikan jumlah pendapatan yang akan diperoleh dari investasi yang dilakukan. Saat ini indikator untuk membaca potensi sukses tidaknya suatu film masih mengandalkan reputasi film, khususnya terkait dengan status pembuat film, genre, box office, dan artis film (Kerrigan \& Özbilgin, 2004).

Perkembangan media digital dan perubahan perilaku konsumsi media seperti yang telah dijelaskan di atas tentunya mempengaruhi strategi distribusi, eksibisi, dan bisnis film secara keseluruhan. Misalnya, semakin banyaknya ruang eksibisi digital telah membuka peluang baru bagi pelaku usaha film untuk memasarkan filmnya secara global dan lebih lama. Eksibisi film digital sangat mempengaruhui bisnis film. Apalagi $S V o D$ seperti Netflix, Viu, Genflik, dll saat ini sangat agresif dalam mendistribusikan film di pasar digital secara global dan menjadikan persaingan bisnis film semakin ketat. Situasi tersebut jika tidak segera direspon dengan baik tentunya dapat mengakibatkan semakin sulitnya film nasional mendapatkan penonton.

Seperti yang terjadi di banyak negara, bioskop di Indonesia juga masih berada dalam dominasi Hollywood atau berkisar di angka $30 \%$. Pada tahun 2019 dari 10 film yang masuk kategori box office, hanya dua film nasional yang berhasil masuk yaitu, "Dilan" dan "Dua Garis Biru". Tidak saja mendominasi pertunjukan di bioskop, film Hollywood juga mendominasi hampir di seluruh tahapan produksi film, mulai dari tahap pra produksi, produksi, hingga paska produksi. Bahkan Eropa, sebagai pionir industri film dan pernah memimpin pasar film dunia saat ini juga masih terjebak dalam dominasi Hollywood. Di Eropa terdapat 39-46\% film Amerika yang ditonton oleh 66-76\% penonton. Film Eropa menguasai mayoritas bioskop, yaitu $45-53 \%$ tetapi penontonnya hanya $22-33 \%$. Selebihnya adalah film dari luar Eropa yang jumlahnya kurang dari $2.5 \%$ dan ditonton kurang dari $0.2 \%$. Sedangkan, produksi film di luar Amerika Serikat dan Eropa berkisar 6-7\% (Garon, 2013).

Rendahnya jumlah penonton film nasional selain diakibatkan oleh rendahnya kualitas film juga dikarenakan distribusi dan eksibisinya masih bergantung pada pasar film nasional dan pertunjukan film melalui bioskop. Padahal bioskop di Indonesia belum merata, jumlah jam tayang dan layar yang tersedia terbatas, dan daya beli masyarakat juga masih rendah. Akibatnya, banyak film bagus sepi penonton karena tidak memiliki ruang dan waktu penayangan yang memadai. Sedangkan pemerintah hingga kini masih memprioritaskan aspek produksi meskipun temuan penelitian membuktikan kunci sukses sebuah film ada pada aspek distribusi (Carroll Harris, 2018).

Oleh karena itu, untuk meningkatkan jumlah penonton dan pendapatan maka distribusi dan eksibisi film tidak boleh hanya bergantung pada bioskop dan pasar film nasional. Pelaku usaha film harus mulai terbiasa dan pandai 
Cici Eka Iswahyuningtyas ${ }^{1}$, dan Mochammad Fadjar H:

Strategies and Challenges in Conventional and Digital Film Distribution and Exhibition in Indonesia Strategi Dan Tantangan Dalam Distribusi Dan Eksibisi Film Secara Konvensional Maupun Digital Di Indonesia

memanfaatkan berbagai ruang eksibisi non bioskop yang tersedia, dengan jumlah penduduk 274 juta dan menduduki peringkat ke empat negara berpenduduk terbesar di dunia, pasar film domestik saja sebetulnya sudah sangat menjajikan. Apalagi, peringkat pertama dan kedua juga diduduki negara dari benua Asia, yaitu Tiongkok (1.6 milyar) dan India (1.4 milyar) (KataData, 2020). Sebagai sesama negara Asia, Indonesia tentunya memiliki kedekatan budaya dan geografis dengan kedua negara tersebut termasuk dengan negara di benua Asia lainnya. Penduduk Asia secara keseluruhan menguasai $60 \%$ jumlah penduduk dunia, ini artinya Asia adalah pasar film strategis bagi Indonesia karena dengan kedekatan budaya dan geografis yang dimiliki film Indonesia memiliki peluang yang lebih besar untuk diterima.

Berdasarkan pada penjelasan di atas, tantangan terbesar distribusi dan eksibisi film tidak hanya terletak pada jumlah bioskop dan layar yang tersedia karena pada kenyataannya banyak film mendapatkan jatah slot layar dalam jumlah besar justru sepi penonton, dengan semakin berkembangnya platform eksibisi secara digital dan semakin tingginya pengguna media digital maka pemerintah dan pelaku usaha film perlu segera mengambil langkah serius dalam merespon situasi tersebut. Namun, fakta bahwa saat ini pendapatan film terbesar masih berada pada eksibisi film melalui jalur bioskop maka strategi distribusi dengan mensinergikan pendekatan konvensional dengan digital dipercaya sebagai cara strategis dalam distribusi dan eksibisi film. Hal ini karena pada era digital seperti sekarang ini, distribusi dan eksibisi tidak bisa hanya bergantung pada satu platform media (Van Hemert \& Ellison, 2015). Kenyataan di atas menunjukkan pentingnya mengkaji sejarah dan pengalaman dunia, khususnya industri film nasional sehingga kedepannya pemerintah dan para pelaku usaha film dapat merumuskan strategi dan kebijakan yang tepat. Berdasarkan pada penjelasan di atas, tulisan ini dimaksudkan untuk mengkaji strategi dan tantangan distribusi dan eksibisi film baik secara konvensional maupun digital dan juga regulasi yang dibutuhkan untuk memajukan dan melindungi film nasional.

\section{Metode Penelitian}

Penelitian ini dijalankan secara kualitatif dengan melakukan kajian pustaka melalui analisis meta. Menurut (Neuman, 2014) analisis meta digunakan secara khusus untuk menciptakan integratif review terhadap temuan utama penelitian sebelumnya yang relevan dengan tujuan penelitian. Literatur yang digunakan dalam tulisan ini berupa jurnal ilmiah, reports, artikel website dan peraturan pemerintah. Analisis meta dilakukan dengan mengkaji literatur yang dipublikasikan lima tahun terakhir karena pada periode tersebut distribusi dan eksibisi film secara digital menunjukkan peningkatan signifikan dengan menguasai sekitar 40-48\% dan sisanya untuk pasar film bioskop dan rilisan fisik (Motion Picture Association, 2019). Selain itu dalam rentang tahun tersebut banyak lahir provider film digital seperti Viu (2016), iflix (2014), Goplay (2018) dll. Walaupun demikian, tidak semua literatur yang ditemukan dalam periode tersebut digunakan dalam kajian ini. Literatur akan diseleksi lagi diantaranya dengan memperhatikan negara tempat penelitian dilakukan. Negara yang dipilih yaitu, Amerika Serikat karena negara ini memimpin industri film dunia. Selanjutnya, adalah Eropa karena sebelum kejayaan 
Hollywood, Eropa adalah pusat industri dan perkembangan teknologi film dunia, khususnya Inggris, Prancis dan Jerman. Terakhir adalah Korea Selatan karena negara tersebut adalah negara Asia yang sukses mendistribusikan film dan dramanya secara global dan melahirkan Hallyu atau Korean Wave di tingkat global. Pencarian literatur dilakukan melalui EBSCOhost, ProQuest ScienceDirect, dan berbagai web relevan dan terpercaya seperti Motion Picture Association (MPA), GlobalWebindex, Film Indonesia (FI), dll. Pencarian dilakukan dengan menggunakan kata kunci diantaranya film distribution, film exhibition, film industry, conventional and digital media, film regulations, dll. Selanjutnya, untuk memperdalam temuan dan perspektif kajian, maka kreteria penentuan literatur tidak dibatasi pada kata kunci tersebut.

\section{Hasil Penemuan dan Diskusi \\ Distribusi dan Eksibisi Film Secara Konvensional}

Daya saing dan keberhasilan suatu film ditentukan oleh banyak faktor yaitu pemasaran, promosi, genre, popularitas, selera pribadi, akting, skenario, jalan cerita, latar, animasi, efek visual, musik, dll (Mardianto et al., 2019). Temuan penelitian tersebut menunjukkan bahwa untuk menghasilkan film berkualitas dan sukses di pasar diperlukan kecermatan dalam seluruh tahapan pembuatannya mulai dari pengembangan ide, pra produksi, produksi, hingga paska produksi. Kesuksesan suatu film tidak ditentukan oleh jumlah penghargaan yang didapatkan tetapi oleh jumlah penonton dan pendapatan yang dihasilkan. Produksi film melibatkan banyak pihak dan memerlukan biaya yang tidak murah. Agar tetap produktif dalam berkarya pembuat film harus mampu memasarkan filmnya seluas dan selama mungkin untuk memperoleh keuntungan sebesar mungkin. Film yang bagus belum tentu sukses di pasar, sebaliknya film yang biasa saja jika dipasarkan dengan baik bisa sukses di pasar. Di era konvergensi media ini, untuk menjangkau khalayak luas, distribusi dan eksibisi film tidak boleh bergantung pada satu platform media, para penggiat film harus bisa memanfaatkan sebanyak mungkin ruang eksibisi yang tersedia.

Perlu diketahui bahwa distributor film konvensional dan digital memiliki pendekatan yang berbeda dalam memahami distribusi. Distributor konvensional fokus pada upaya mendatangkan penonton ke bioskop sebanyak mungkin dan menduduki peringkat box office. Sedangkan Subscription Video on Demand (SVoD) mengedepankan upaya meningkatkan lalu lintas online dan jumlah subcribers atau pelanggan. Perubahan pola konsumsi media dan semakin banyaknya provider digital pada satu sisi memang mengakibatkan persentase pertumbuhan penonton film jalur konvensional lebih rendah jika dibandingkan dengan digital. Meskipun demikian dari segi bisnis, potensi ekonomi eksibisi film melalui jalur bioskop masih menjanjikan. Bercermin dari apa yang terjadi pada industri musik, meskipun saat ini rilisan musik digital tumbuh pesat tetapi rilisan fisik atau konvensional masih memiliki peminat tersendiri. Khalayak tidak sepenuhnya setuju dan menolak rilisan fisik dan digital sehingga dalam distribusi musik, musisi perlu secara simultan mengkombinasikan rilisan digital dan fisik (Putra, 2019). Ini artinya, dalam bisnis konten media, termasuk halnya bisnis film yang harus dilakukan adalah bagaimana 
Cici Eka Iswahyuningtyas ${ }^{1}$, dan Mochammad Fadjar H:

Strategies and Challenges in Conventional and Digital Film Distribution and Exhibition in Indonesia Strategi Dan Tantangan Dalam Distribusi Dan Eksibisi Film Secara Konvensional Maupun Digital Di Indonesia

menyusun strategi distribusi yang tepat bagi setiap konten yang diproduksi guna memperoleh penonton dan pendapatan sebanyak-banyaknya.

Masih menjanjikannya eksibisi film melalui jalur bioskop dapat dilihat dari data statistik yang menunjukkan pertumbuhan signifikan penonton bioskop nasional dalam 5 (lima) tahun terakhir. Pada tahun 2015 hingga 2020 secara berturut-turut telah meningkat sebanyak 16.2 juta pada tahun 2015, tahun 2016 sebanyak 37.2 juta, tahun 2017 sebanyak 42.7 juta, tahun 2018 sebanyak 52 juta. Selanjutnya, tahun 2019 hingga 2020 diprediksi meningkat menjadi 60 juta penonton (KataData, 2019). Hasil Survey Saiful Mujani Research \& Consulting (SMRC) tentang penonton film bioskop di kota besar menunjukkan $67 \%$ kaum muda berusia 15-38 tahun menonton film di bioskop setidaknya sekali setahun dan $81 \%$ diantaranya setidaknya menonton satu film nasional setiap tahunnya (SMRC, 2019).

Tidak hanya jumlah penonton, jumlah bioskop dan layar juga mengalami pertumbuhan signifikan, dari 145 bioskop dan 609 layar pada tahun 2012 meningkat menjadi 263 bioskop dan 1412 layar pada tahun 2016. Selanjutnya, tahun 2018 meningkat menjadi 343 bioskop dan 1.756 layar. Bioskop juga sudah tersebar di 32 privinsi kecuali provinsi DI Aceh dan Kalimantan Utara. Dilihat dari persebaranya hingga Desember 2018, 80\% bioskop masih terpusat di ibukota provinsi dan sisanya $20 \%$ berada di kabupaten. Persebaran bioskop di ibu kota provinsi mayoritas berada di pulau Jawa, yaitu Jakarta, Bandung, Surabaya, Solo dan DIY Yogyakarta (Mediarta, 2018).

Pertumbuhan jumlah bioskop dan layar tersebut didorong masuknya jaringan bioskop baru. Hingga Desember 2017 terdapat enam jaringan bioskop dan bioskop independent, yaitu, Cinemaxx (48 bioskop) dan New Star Cineplex, Platinum Cineplex dan Moviemax memiliki 58 bioskop. Masuknya kompetitor baru dalam bisnis bioskop ini berhasil menggeser dominasi group Cinema 21 dan CGV yang sebelumnya menguasai 90 persen jaringan bioskop. Pada tahun 2017 penguasaan jaringan bioskop group Cinema 21 (186 bioskop) dan CGV (54 bioskop) atau berkurang menjadi 63\%. Pertumbuhan bioskop yang sebelumnya terkonsentrasi pada ibu kota provinsi, khususnya di pulau Jawa, saat ini sudah mulai bergeser ke kota kabupaten (Ramadani, 2018) (Lidwina, 2019). Pertumbuhan bioskop seperti yang telah dijelaskan di atas menunjukkan bahwa eksibisi film secara konvensional masih menjajikan. Terlebih, dengan 274 juta jumlah penduduk di tahun 2020 ini, pasar film nasional Indonesia cukup potensial untuk dikembangkan.

Masalahnya adalah meskipun jumlah penonton dan ruang eksibisi film melalui bioskop terus meningkat tetapi film Indonesia masih sepi penonton dan sulit menempati posisi box office film nasional. Situasi tersebut terjadi karena keberhasilan film dalam mendapatkan penonton tidak hanya ditentukan oleh jumlah layar dan bioskop tetapi juga strategi distribusi dan eksibisi yang tepat. Setiap film punya karakteristik dan kebutuhan berbeda sehingga memerlukan pendekatan distribusi dan eksibisi yang juga berbeda (Kehoe \& Mateer, 2015). Maka dari itu untuk mendapatkan respon positif, pelaku usaha film khususnya distributor dan produser perlu menetapkan segmentasi pasar, yaitu segmentasi geografi, demografi, psikografi dan perilaku. Selain itu strategi pemasaran terkait produk, harga, 
distribusi dan promosi juga perlu ditetapkan pada setiap film yang diproduksi (Wahyudi, 2018).

Tantangan dalam distribusi dan eksibisi film tidak hanya terletak pada jumlah bioskop dan layar tetapi bagaimana membuat penonton bisa lebih terhubung dan mendapatkan pengalaman personal dengan pembuat dan pemain film. Hal ini bisa diwujudkan melalui road show. Melalui road show penonton tidak hanya berkesempatan untuk menonton film dan mendapatkan suasana bioskop tetapi juga dapat berinteraksi secara langsung dengan para pembuat film dan artis pendukungnya (Gaunson, 2017). Namun perlu diketahui bahwa metode ini tidak berhasil untuk semua film karena pada film tertentu, strategi distribusi melalui road show atau tuor sukses mendapatkan jumlah penonton tetapi tidak berhasil bagi film lainnya. Oleh karena itu, untuk mendapatkan sambutan positif, distributor dan produser film perlu melakukan evaluasi dan analisis terkait karakteristik film, khalayak sasaran, dan strategi distribusi dan eksibisi yang mereka lakukan.

Strategi selanjutnya adalah terkait bentuk kerjasama dengan bioskop. Distributor dan produser film perlu bersama-sama menentukan model distribusi dan eksibisi, seperti jumlah layar, sistem bagi hasil, dan waktu penayangan. Mengingat selama ini hal tersebut masih dikendalikan sepenuhnya oleh pihak bioskop padahal produser film seharusnya adalah pihak yang paling mengetahui karakteristik film yang mereka produksi. Selain itu, distributor dan produser film juga perlu memahami karakteristik penonton film dan memiliki informasi lengkap tentang target pasarnya. Misalnya, mengetahui bagaimana penonton mendapatkan dan mengakses film, genre film yang diminati, daya beli, dll karena perilaku konsumsi media dan preferensi khalayak menentukan apakah suatu film ditonton atau tidak,

Terakhir, mengingat film Indonesia masih kurang diminati dan bergantung pada pasar film nasional maka strategi day and date dalam distribusi film perlu dikembangkan. Pada strategi ini film dirilis simultan secara konvensional dan digital. Strategi ini efektif untuk mengenalkan film dan mendapatkan publikasi dan perbincangan luas dari media dan publik. Eksibisi film melalui bioskop penting untuk menciptakan pengetahuan khalayak mengenai film sebelum diputar secara digital (Smits et al., 2018). Pemutaran film di bioskop juga dapat dimanfaatkan sebagai event resmi peluncuran film. Publikasi dan perbincangan film pada media mainstream dan sosial diperlukan untuk mempromosikan dan mendorong minat publik untuk melihat teaser dan ulasan untuk selanjutnya menonton film. Eksibisi film melalui jalur bioskop juga dapat meningkatkan keberhasilan distribusi film secara digital karena film dengan rating penonton tinggi akan masuk dalam rekomendasi algoritma untuk ditonton.

\section{Distribusi dan Eksibisi Film Secara Digital}

Era digital membuka peluang baru bagi pelaku usaha film untuk memperluas pasar. Hal ini karena media digital telah mengubah perilaku khalayak dalam mengkonsumsi media. Di era digital sebuah konten media bisa ditonton oleh jutaan orang dalam hitungan menit, dibagikan dalam hitungan detik, dan melahirkan aktivitas jaringan sosial yang tidak terhitung jumlahnya. Melalui koneksi internet khalayak bisa menonton film kapanpun dan dimanapun, berbagai genre, dan juga bisa menontonnya dengan menggunakan beragam teknologi 
Cici Eka Iswahyuningtyas ${ }^{1}$, dan Mochammad Fadjar H:

Strategies and Challenges in Conventional and Digital Film Distribution and Exhibition in Indonesia Strategi Dan Tantangan Dalam Distribusi Dan Eksibisi Film Secara Konvensional Maupun Digital Di Indonesia

komunikasi (tablet, mobile, PC, dll), web maupun aplikasi. Selanjutnya, dilihat dari aspek bisnis media, sistim media digital juga tidak memerlukan modal besar, lebih sederhana, sejalan dengan perubahan gaya hidup masyarakat, mendorong persaingan bisnis yang lebih sehat dan terbuka sehingga siapa saja bisa terlibat di dalamnya (Toni, 2016).

Data global tentang waktu penggunaan media harian menunjukkan bahwa rerata audiens menghabiskan waktunya untuk mengakses media digital lebih dari 6 jam atau $60 \%$ total penggunaan media hariannya. Dimana $34 \%$ digunakan untuk mengakses media sosial, $17 \%$ TV online, $18 \%$ music streaming, $15 \%$ surat kabar digital dan sisanya 16\% lainnya (Gobalwebindex, 2019). Kondisi ini menunjukkan bahwa saat ini ketersediaan bioskop bukanlah masalah besar dalam distribusi dan eksibisi film. Apalagi saat ini provider penyedia ruang eksibisi secara digital juga semakin banyak dan terjangkau. Baik melalui Video on Demand (Netflix, Viu, Iflix, dll), Electronic Sell Through (Amazon Video, iTune Store, Walmart, dll) maupun Multichannel Video Programming Distributor (Indovision, MNC Play, IndiHome, dll). Semakin banyaknya provider menjadikan pasar film digital berkembang semakin pesat. Tingginya pertumbuhan tersebut tentunya membuka peluang besar bagi pelaku usaha film. Pasar film digital memerlukan ketersediaan film dalam jumlah tak terhingga, berbagai genre, cerita, dan usia. Pasar film digital juga memungkinkan film lama untuk tetap mendapatkan penonton. Oleh karena itu, distributor dan produser film perlu segera keluar dari ketergantungan pada model distribusi dan eksibisi film secara konvensional. Laporan MPA 2019 menunjukkan bahwa di tingkat global terjadi peningkatan penonton film digital secara signifikan, bahkan dari tahun 2018 hingga 2019 pendapatan film digital meningkat 29\% (Motion Picture Association, 2019).

Data dari AC Nielsen 2017 menunjukkan bahwa penonton film di Indonesia didominasi oleh kelompok penonton usia 20-34 tahun sejumlah 51 persen, kemudian diikuti oleh penonton anak/remaja usia 10-19 tahun sejumlah 33 persen. Sedangkan pengguna internet tumbuh $13.3 \%$ pada tahun 2018 atau meningkat dari 84 juta menjadi 95.2 juta pengguna. Pada tahun 2018 hingga 2023 diperkirakan akan meningkat sebesar 10.2\% (Jayani, 2019). Ini artinya pasar film digital memiliki masa depan yang menjanjikan mengingat mayoritas penonton film kita adalah pengguna teknologi digital.

Sayangnya, meskipun Indonesia memiliki pasar film domestik yang besar tetapi masih terkendala dengan akses internet dan ketersediaan teknologi komunikasi. Menurut (Huffer, 2017) kemampuan khalayak mengakses film secara digital dipengaruhi oleh kondisi ekonomi dan teknologi komunikasi. Kedua faktor tersebut menentukan kemampuan khalayak dalam mengkonsumsi film secara kontemporer atau digital. Oleh karena itu, pengetahuan tentang kondisi demografis khalayak sasaran diperlukan. Meskipun saat ini pasar film digital di tingkat domestik belum terlalu menjajikan namun tentunya melalui platform media digital film Indonesia memiliki peluang yang besar untuk ditonton secara global dan dalam waktu yang lebih lama.

Model distribusi dan eksibisi film secara digital tidak saja memperluas pasar film tetapi juga memperpanjang usia film dan memungkinkan film lama tetap mendapatkan penonton. Sebagai contoh eksibisi film secara digital membuka 
peluang bagi film era Orde Baru kembali ditayangkan. Bahkan film ini mendapatkan respon positif dari pasar film global karena dalam strategi pemasaran dan branding yang dilakukan menonjolkan mutual interaksi antara western cult-fun boys dan mistisme atau eksotisme timur. Target penontonnya adalah pecinta film horror dan film berbudget rendah. Distributor film membidik pasar minoritas di luar pasar film mainstream yang menyukai eksotisme dan konten film yang tidak biasa (Imanjaya, 2009).

Meskipun pendapatan dari eksibisi film secara digital cenderung lebih lambat dibandingkan secara konvensional namun eksibisi film secara digital penting untuk meningkatkan pendapatan dalam jangka panjang. Oleh karena itu, dalam distribusi dan eksibisi film, produser dan distributor dituntut kreatifitasnya dalam membuat strategi promosi yang tepat, terutama melalui media sosial. Mereka perlu lebih serius dalam mengembangkan model distribusi dan eksibisi film dan tidak lagi bergantung pada pendapatan dari model konvensional (Van Hemert \& Ellison, 2015).

Dalam distribusi dan eksibisi film secara digital, promosi merupakan faktor penting. Oleh karena itu, promosi film melalui media sosial penting dilakukan untuk mendorong performa film. Strategi ini penting untuk melindungi bisnis dan mendapatkan pendapatan jangka panjang. Kemampuan dalam menggunakan dan mengelola media sosial diperlukan untuk mendapatkan promosi secara gratis dan luas. Media sosial adalah alat efektif dalam mendapatkan perhatian dan target audiens. Untuk mendapatkan data akurat distributor dan produser film dapat memanfaatkan data traffic yang disediakan provider media sosial (Holmene, 2018). Selain itu, promosi film melalui media sosial juga dapat dilakukan melalui Forum Sharing. Forum ini penting dalam promosi film karena melalui forum tersebut film dicari, diinterpretasi, disebarkan, dipromosikan, direkomendasikan dan diulas oleh banyak orang (Crisp, 2012).

\section{Dukungan Pemerintah dalam Distribusi dan Eksibisi Film}

Sejak awal kehadirannya, film Indonesia banyak dipengaruhi oleh regulasi, situasi ekonomi, sosial, politik, dan perkembangan teknologi komunikasi. Kondisi tersebut menunjukkan bahwa dukungan pemerintah dalam mengembangkan industri film sangat diperlukan karena iklim usaha yang kondusif tidak akan tercipta tanpa adanya dukungan dari pemerintah (Putri, 2017). Penelitian tentang sejarah perkembangan film menunjukkan bahwa industri film tanah air menghadapi banyak tantangan dan untuk keluar dari permasalahan yang ada diperlukan kebijakan terkait pengembangan sekolah film, subsidi produksi film, pengembangan komunitas film, menumbuhkan nasionalisme film, dan juga distribusi dan eksibisi (Ardiyanti, 2020).

Bentuk dukungan pemerintah dapat dipelajari dari apa yang telah dilakukan oleh New Zealand, Jerman, Swedia dan Rusia. Pemerintah New Zealand memberikan subsidi langsung untuk eksibisi film melalui bioskop dengan memberikan bantuan biaya hingga $25 \%$. Di Jerman, Film dengan biaya produksi di bawah 250.000 USD dibebaskan dari pajak dan diberikan subsidi distribusi secara langsung. Pemerintah Spanyol memberikan bantuan subsidi distribusi film sebesar $50 \%$ untuk film tertentu dan juga kebijakan quota film di bioskop bagi film 
Cici Eka Iswahyuningtyas ${ }^{1}$, dan Mochammad Fadjar H:

Strategies and Challenges in Conventional and Digital Film Distribution and Exhibition in Indonesia Strategi Dan Tantangan Dalam Distribusi Dan Eksibisi Film Secara Konvensional Maupun Digital Di Indonesia

nasional yaitu, 73-91 hari per tahun. Pemerintah Swedia memberikan subsidi eksibisi film di bioskop dan membedakan pajak bagi film lokal box office $(10 \%)$ dan non box office (6\%). Pemerintah Australia memberikan potongan pajak, membuat lembaga khusus yang menangani pasar film global dan memberikan bantuan tunai bagi bioskop yang memutar film dengan penonton kurang dari 200 ribu (Carroll Harris, 2018). Selanjutnya, Rusia memberikan subsidi modernisasi bioskop karena pertunjukan film di bioskop terbukti mempengaruhi produksi dan distribusi film secara keseluruhan (Lanina \& Malyshev, 2019).

Sayangnya, intervensi pemerintah dalam melindungi industri film nasional pada umumnya masih fokus pada insentif bantuan langsung pada tahap produksi. Padahal meskipun industri film di Korea Selatan minim bantuan langsung dari Pemerintah tetapi industri filmnya justru berkembang pesat. Kunci sukses Korea Selatan adalah adanya program pemberian bantuan tidak langsung seperti pengembangan infrastruktur produksi (Studio dan Sekolah) dan infrastruktur distribusi (Bioskop dan Film festival) (Messerlin, 2019).

Pemerintah Korea Selatan juga menerapkan sistim quota dengan memaksa bioskop memutar film lokal sekurangnya 146 hari per tahun. Kebijakan ini penting untuk meningkatkan waktu tayang dan jumlah film nasional yang diputar di bioskop. Langka ini diambil karena meskipun pasar film digital meningkat tetapi saat ini lebih dari $80 \%$ pendapatan film mereka masih berasal dari eksibisi film melalui jalur bioskop (Dooboo Shimp, 2011). Kebijakan tersebut berhasil meningkatkan jumlah penonton film di bioskop. Mengingat film Indonesia juga masih berada dalam dominasi Hollywood maka pemerintah juga perlu mempertahankan kebijakan quota film demi melindungi film lokal dari gempuran film asing. Insentif pemerintah dapat dilakukan melalui pemberian potongan pajak, subsidi distribusi, sistim quota, membuat lembaga khusus yang menanggani distribusi film global, insentif bagi bioskop yang memutar film dengan penonton sedikit, dll. Dukungan pemerintah dalam melindungi dan memajukan film nasional diperlukan karena film sebagai karya kreatif memerlukan komitmen pemerintah dalam menyediakan infrastruktur dan payung hukum yang berpihak kepada film nasional. Terakhir, pemerintah juga perlu meningkatkan kerjasama bisnis film di tingkat global, khususnya dengan negara-negara di wilayah Asia yang memiliki kedekatan geografis dan budaya. Dengan memiliki jumlah penduduk sebesar $60 \%$ maka film Indonesia memiliki peluang yang lebih besar untuk diterima di pasar film Asia dibandingkan pasar film lainnya.

\section{Simpulan}

Distribusi dan eksibisi film perlu dilakukan secara simultan melalui ruang pertunjukan konvensional maupun digital. Hal ini karena untuk memperluas pasar, pelaku usaha film tidak boleh hanya bergantung pada satu platform media. Eksibisi film secara digital penting dilakukan karena ruang eksibisi konvensional masih terkendala dengan jumlah bioskop, layar, posisi bioskop yang terpusat di kota besar, harga tiket, dan dominasi film asing. Meskipun saat ini pendapatan eksibisi film secara digital belum terlalu besar tetapi melihat pergeseran pola konsumsi media dan semakin banyaknya provider digital menunjukkan besarnya potensi pasar film 
digital untuk dikembangkan. Selain itu, eksibisi film secara digital dapat memperpanjang usia film, memperluas pasar film, dan meningkatkan pendapatan dalam jangkah panjang.

Sayangnya, meskipun pasar film digital lebih menjanjikan namun melihat trend pertumbuhan penonton bioskop yang masih terus menunjukkan peningkatan maka pertunjukan film secara konvensional perlu dipertahankan. Langkah tersebut diperlukan karena jumlah bioskop dan penonton film nasional ke depannya diprediksi masih terus meningkat. Selain itu eksibisi film melalui bioskop juga mampu meningkatkan publikasi, perbincangan, dan mendorong penjualan film di pasar digital. Untuk meningkatkan jumlah penonton dapat dilakukan dengan pemerataan dan modernisasi infrastruktur bioskop. Mengingat setiap film memiliki karakteristik yang berbeda maka setiap film juga memerlukan model distribusi dan eksibisi yang juga berbeda. Selanjutnya, sebagai pihak yang paling mengenal film yang mereka produksi, produser film harus terlibat secara aktif dalam menentukan model distribusi dan eksibisi, dan tidak lagi menyerahkan sepenuhnya kepada pihak bioskop.

Selanjutnya, terkait dengan dukungan pemerintah, dapat dilakukan dengan menetapkan regulasi dan memberikan insentif secara menyeluruh, tidak hanya pada tahap pengembangan, pra produksi, dan produksi tetapi juga tahap paska produksi. Dukungan pemerintah dapat dilakukan dengan menetapkan kebijakan quota dan waktu penayangan, memberikan insentif pertunjukan dan promosi, potongan pajak bagi film dengan sedikit penonton, dan mengembangkan infrastruktur distribusi seperti bioskop dan film festival. Selanjutnya, untuk meningkatkan distribusi film di tingkat global, pemerintah perlu mendirikan lembaga khusus yang bertanggung jawab dalam membantu dan menangani distribusi dan eksibisi film di tingkat global.

\section{Ucapan Terima Kasih}

Ucapan terima kasih yang sebesar-besarnya disampaikan kepada pimpinan dan dosen di Fakultas Ilmu Komunikasi, Universitas Pancasila yang telah memberikan bantuan dana, pemikiran, dan memfasilitasi pelaksanaan penelitian ini. Selanjutnya,penulis juga menyampaikan terima kasih kepada semua pihak yang telah memberikan banyak dukungan dan masukan berharga sehingga tulisan ini bisa diselesaikan.

\section{Daftar Pustaka}

Ardiyanti, H. (2020). Perfilman Indonesia: Perkembangan Dan Kebijakan, Sebuah Telaah Dari Perspektif Industri Budaya Cinema in Indonesia: History and Goverment Regulation, a Cultural Industry Perspective. Jurnal.Dpr.Go.Id, 22(August).

Asia-Pacific-Media MarketLine Industry Profile Media in Asia-Pacific. (2017). MarketLine. 
Cici Eka Iswahyuningtyas ${ }^{1}$, dan Mochammad Fadjar H:

Strategies and Challenges in Conventional and Digital Film Distribution and Exhibition in Indonesia Strategi Dan Tantangan Dalam Distribusi Dan Eksibisi Film Secara Konvensional Maupun Digital Di Indonesia

Carroll Harris, L. (2018). Film distribution as policy: current standards and alternatives. International Journal of Cultural Policy, 24(2), 236-255. https://doi.org/10.1080/10286632.2016.1156100

Crisp, V. (2012). Bloody Pirates!!!* shakes fist*': Reimagining East Asian film distribution and reception through online filesharing networks. Journal of Japanese and Korean Cinema. https://doi.org/10.1386/jjkc.3.1.65_1

Dooboo Shimp, B. (2011). Whither The Korean Film Industry?^. In 214 Acta Koreana (Vol. 14, Issue 1). www.koreanfilm.or.kr

Garon, J. M. (2013). Digital Hollywood 2.0: Reimagining Film, Music, Television, and Publishing Distribution as a Global Artist Collaborative. Mich. St. U. Coll. L. Int'l L. Rev.

Gobalwebindex. (2019). Digital vs Traditional Media Consumption. www.globalwebindex.com

Holmene, I. (2018). Paid or semi-public media? The norwegian film industry's strategies for social media. Northern Lights, 16(1), 41-57. https://doi.org/10.1386/nl.16.41_1

Huffer, I. (2017). Social inclusivity, cultural diversity and online film consumption. Cultural Trends. https://doi.org/10.1080/09548963.2017.1323844

Imanjaya, E. (2009). The Other Side of Indonesia: New Order's Indonesian Exploitation Cinema as Cult Films 1 Ekky Imanjaya. www.colloquy.monash.edu.au/issue18/imanjaya.pdf

Jayani, D. H. (2019). Berapa Pengguna Internet di Indonesia? KataData. https://databoks.katadata.co.id/datapublish/2019/09/09/berapa-penggunainternet-di-indonesia

KataData. (2019). Bekraf Targetkan Penonton Bioskop 2019 Tumbuh 15\%. KataData. https://databoks.katadata.co.id/datapublish/2019/02/25/bekraftargetkan-penonton-bioskop-2019-tumbuh-15

KataData. (2020). Penduduk Indonesia Terbesar Keempat Dunia. https://databoks.katadata.co.id/datapublish/2019/12/16/2020-pendudukindonesia-terbesar-keempat-dunia

Kehoe, K., \& Mateer, J. (2015). The Impact of Digital Technology on the Distribution Value Chain Model of Independent Feature Films in the UK. JMM International Journal on Media Management. https://doi.org/10.1080/14241277.2015.1055533

Kerrigan, F., \& Özbilgin, M. (2004). Film marketing in Europe: bridging the gap between policy and practice. International Journal of Nonprofit and Voluntary Sector Marketing. https://doi.org/10.1002/nvsm. 250

Lanina, L. A., \& Malyshev, A. V. (2019). Target Subsidies As A Film Screening Development Tool In Russian Regions. Vestnik Universiteta, 4. https://doi.org/10.26425/1816-4277-2019-4-75-82

Lidwina, A. (2019). Berapa Jumlah Gedung dan Layar Bioskop di Indonesia? KataData. https://databoks.katadata.co.id/datapublish/2019/10/18/berapajumlah-gedung-dan-layar-bioskop-di-indonesia 
Mardianto, M. F. F., Hastuti, D. R., Husada, D. A., \& Andriawan, R. (2019). Comparative analysis of the competitiveness between Indonesian movies against international movie, as a reference in developing Indonesia's cinema and curriculum about cinematography. International Journal of Innovation, Creativity and Change, 5(3).

MarketLine Industry Profile Global Media. (2014).

Mediarta, A. (2018). Kaleidoskop 2017: Mengukur detak jantung industri film Indonesia. Film Indonesia. http://filmindonesia.or.id/article/kaleidoskop2017-mengukur-detak-jantung-industri-film-indonesia\#.X8pAVbnivIU

Messerlin, P. (2019). Building consistent policies on subsidies in the film industry: Institutions and instruments in France and Korea. Kritika Kultura. https://doi.org/10.13185/2991

Motion Picture Association. (2019). A comprehensive analysis and survey of the theatrical and home/mobile entertainment market environment for 2019. https://www.motionpictures.org/research-docs/2019-theme-report/

Neuman, W. L. (William L. (2014). Social research methods: qualitative and quantitative approaches (Seventh Ed). Pearson Education Limited.

Putra, R. M. (2019). Musik Rilisan Fisik Di Era Digital: Musik Indie Dan Konsumsi Rilisan Musik Fisik. Jurnal Komunikasi, 11(2), 128-140.

Putri, I. P. (2017). Industri Film Indonesia Sebagai Bagian Dari Industri Kreatif Indonesia. Jurnal Ilmiah LISKI (Lingkar Studi Komunikasi), 3(1). https://doi.org/10.25124/liski.v3i1.805

Ramadani, D. (2018). Kaleidoskop 2017: Bioskop yang Belum Ramah bagi Semua. Film Indonesia. http://filmindonesia.or.id/article/kaleidoskop-2017bioskop-yang-belum-ramah-bagi-semuatahun-2017-bioskop-yang-belumramah-bagi-semua\#.X8o8U7nivIU

Smits, R., Higson, A., Mateer, J., Jones, H. D., \& D’Ippolito, B. (2018). Distributing films online. In Journal of British Cinema and Television (Vol. 15, Issue 2, pp. 291-299). Edinburgh University Press. https://doi.org/10.3366/jbctv.2018.0419

SMRC. (2019). Siapa Menonton Film di Bioskop? https://saifulmujani.com/wpcontent/uploads/2020/01/Presentasi-Final-Film_SMRC_rev.pdf

Toni, A. (2016). Bisnis Media : Pasca Matinya Televisi Nasional Dalam Perspektif Jurnalistik. Jurnal Komunikasi, 8(1), 36-50.

Van Hemert, T., \& Ellison, E. (2015). Queensland's film culture: The challenges of local film distribution and festival exhibition. Studies in Australasian Cinema. https://doi.org/10.1080/17503175.2014.1002269

Wahyudi, S. (2018). How To Win Indonesian Movie Viewer: Case of Village Cinena Australia. Jurnal Bisnis Terapan, 2(01). https://doi.org/10.24123/jbt.v2i01.1084 